\title{
ANALISIS PENGARUH LIKUIDITAS DAN PEMBERIAN KREDIT TERHADAP TINGKAT PROFITABILITAS PADA BANK BPR MEGA MAS LESTARI TAHUN 2016-2018 KABUPATEN KARIMUN
}

\author{
${ }^{1}$ Fauzan Haqiqi, ${ }^{2}$ Darmawan ${ }^{3}$ Kasirul Fadli \\ ${ }^{1}$ Program Studi Akuntansi, Fakultas Ilmu Sosial dan Humaniora, Universitas Karimun, \\ Provinsi Kepulauan Riau, Indonesia. \\ Email : fauzanhaqiqi.1986@gmail.com \\ ${ }^{2}$ Program Studi Akuntansi, Fakultas Ilmu Sosial dan Humaniora, Universitas Karimun, \\ Provinsi Kepulauan Riau, Indonesia. \\ Email : dwan488mawan@gmail.com \\ ${ }^{3}$ Program Studi Akuntansi, Fakultas Ilmu Sosial dan Humaniora, Universitas Karimun, \\ Provinsi Kepulauan Riau, Indonesia. \\ Email : khasirulfadli@gmail.com
}

\begin{abstract}
Abstrak
Salah satu cara perusahaan untuk mendapatkan keuntungan yaitu dengan memberikan kredit pada nasabahnya. Kredit sangat penting bagi profitabilitas karena dengan adanya peningkatan atau perkembangan kredit yang disalurkan setiap tahunnya, maka akan meningkatkan pula profitabilitasnya. Tujuan Penelitian untuk mengetahui pengaruh secara Parsial antara Likuiditas (X1) terhadap Tingkat Profitabilitas (Y), Pemberian Kredit (X2) terhadap Tingkat Profitabilitas (Y) dan untuk mengetahui pengaruh secara Simultan antara Likuiditas (X1) dan Pemberian Kredit (X2) terhadap Profitabilitas (Y) pada Bank BPR Mega Mas Lestari Tahun 2016-2018. Hasil penelitian; Uji t (Parsial) membuktikan Hipotesis Pertama (Ha1) diterima, artinya terdapat pengaruh variabel Likuiditas (X1) terhadap Profitabilitas (Y), dimana nilai thitung $(7,553)>t$ Tabel (2,042), dan berdasarkan nilai signifikan, Nilai sig 0,000 $<0,05$. Uji t (Parsial) membuktikan Hipotesis Kedua (Ha2) ditolak, artinya tidak terdapat pengaruh variabel Pemberian Kredit (X2) terhadap Profitabilitas (Y), dimana nilai thitung $(0,955)<\mathrm{t}$ Tabel $(2,042)$, dan berdasarkan nilai signifikan, Nilai sig 0,347>0,05. Uji f (simultan) membuktikan Hipotesis ketiga (Ha3) diterima artinya terdapat Pengaruh variabel Likuiditas (X1) dan variabel Pemberian Kredit (X2) terhadap Profitabilitas (Y), berdasarkan output SPSS didapati nilai F hitung sebesar 162.883. Karena nilai Fhitung $(162.883)>$ F Tabel $(3,305)$ maka Ha3 Diterima dan Ho3 Ditolak dan berdasarkan nilai sig $0,00<0,05$. Uji Detreminan membuktikan nilai $\mathrm{R}$ Square 0,910 dengan variable independen X1 dan X2. Artinya bahwa kontribusi nilai X1 dan X2 dalam menjelaskan variable $\mathrm{Y}$ ialah sebesar 91,6\% dan dan sisanya 8,4\% dijelaskan oleh variable lain diluar variable yang diuji.
\end{abstract}

Kata Lunci: Likuiditas, Pemberian Kredit, Profitabilitas

\section{PENDAHULUAN}

Pengertian bank adalah lembaga intermediasi keuangan yang bertugas menghimpun dan menyalurkan dana di masyarakat untuk meningkatkan taraf hidup rakyat. Bank sebagai lembaga keuangan yang melakukan penghimpunan dana dari 
masyarakat dan selanjutnya menyalurkan dana tersebut ke masyarakat dalam bentuk kredit. Bank dapat memberikan bermacam-macam jasa pembiayaan, bank juga dapat melayani kebutuhan masyarakat dan dunia usaha pengguna jasa kredit untuk meningkatkan kualitas kehidupan masyarakat. Laba atau keuntungan sangat diharapkan oleh perusahaan untuk mempertahankan kelangsungan hidupnya. Salah satu cara perusahaan untuk mendapatkan keuntungan yaitu dengan memberikan kredit pada nasabahnya. Kredit sangat penting bagi profitabilitas karena dengan adanya peningkatan atau perkembangan kredit yang disalurkan setiap tahunnya, maka akan meningkatkan pula profitabilitasnya. Untuk tetap mempertahankan agar laba suatu perusahaan meningkat, maka kredit yang disalurkan harus pula ditingkatkan. Dalam melakukan kegiatan operasionalnya, bank memiliki tujuan utama yaitu mencapai tingkat profitabilitas yang maksimal. Profitabilitas merupakan kemampuan Bank untuk menghasilkan/memperoleh Laba secara efektif dan efisien. Profitabilitas yaitu kemampuan perusahaan dalam mendapatkan keuntungan yang ditunjukkan oleh laba yang dihasilkan.

Bank BPR Mega Mas Lestari Kabupaten Karimun merupakan salah satu bank umum di Tanjung Balai Karimun yang didirikan berdasarkan Akte Pendirian Nomor: 157, tanggal 25 Oktober 2010 dibuat di hadapan Yonri Darto, SH, Notaris di Batam. Dan ini menjadikan PT. BPR Mega Mas Lestari sebagai BPR yang memiliki gedung sendiri setelah beroperasi \pm 3 Tahun. Dalam memberikan kredit, bank harus mempunyai prinsip kehati-hatian. Kesalahan dalam memberikan kredit akan memberikan resiko yang besar bagi bank. Resiko tersebut berupa resiko tidak tertagihnya pinjaman, dan terlambatnya penerimaan pinjaman dari jadwal, sehingga menimbulkan kredit macet.

Tabel 1.1 Perkembangan Likuiditas PT. Bank BPR Mega Mas Lestari Tahun 20162018 Kabupaten Karimun

\begin{tabular}{|c|r|r|r|}
\hline \multirow{2}{*}{ Bulan } & \multicolumn{3}{|c|}{ Likuiditas } \\
\cline { 2 - 4 } & Tahun 2016 & Tahun 2017 & \multicolumn{1}{c|}{ Tahun 2018 } \\
\hline 1 & 94.139 .000 & 111.890 .083 & 158.744 .416 \\
\hline 2 & 94.188 .100 & 114.544 .000 & 160.160 .000 \\
\hline 3 & 95.001 .000 & 118.320 .000 & 154.441 .600 \\
\hline 4 & 94.872 .200 & 121.830 .080 & 155.744 .000 \\
\hline 5 & 94.743 .000 & 110.000 .300 & 158.001 .000 \\
\hline 6 & 94.563 .900 & 112.800 .830 & 151.622 .000 \\
\hline 7 & 94.222 .000 & 100.914 .224 & 158.700 .000 \\
\hline 8 & 94.197 .000 & 114.830 .100 & 157.441 .600 \\
\hline 9 & 90.174 .368 & 112.200 .000 & 158.740 .000 \\
\hline 10 & 95.133 .000 & 117.008 .300 & 154.161 .000 \\
\hline 11 & 94.211 .532 & 106.900 .083 & 157.400 .416 \\
\hline 12 & 94.222 .900 & 101.443 .000 & 179.776 .968 \\
\hline Jumlah & 1.129 .668 .000 & 1.342 .681 .000 & 1.904 .933 .000 \\
\hline
\end{tabular}

Sumber: Bank BPR Mega Mas Lestari, 2019

Tabel 1.2 Perkembangan Pemberian Kredit PT. Bank BPR Mega Mas Lestari Tahun 2016-2018 Kabupaten Karimun

\begin{tabular}{|c|c|c|c|}
\hline \multirow{2}{*}{ Bulan } & \multicolumn{3}{|c|}{ Jumlah Pemberian Kredit } \\
\cline { 2 - 4 } & Tahun 2016 & Tahun 2017 & Tahun 2018 \\
\hline 1 & 14.847 .518 .083 & 14.419 .965 .500 & 12.545 .164 .333 \\
\hline
\end{tabular}




\begin{tabular}{|c|r|r|r|}
\hline 2 & 14.334 .436 .770 & 14.588 .620 .000 & 12.522 .224 .770 \\
\hline 3 & 15.443 .555 .200 & 14.521 .000 .000 & 12.333 .620 .000 \\
\hline 4 & 15.967 .539 .788 & 14.621 .000 .000 & 12.771 .222 .300 \\
\hline 5 & 14.777 .623 .000 & 14.530 .010 .000 & 12.023 .000 .000 \\
\hline 6 & 14.949 .172 .694 & 14.419 .655 .400 & 13.000 .200 .020 \\
\hline 7 & 15.223 .221 .455 & 14.055 .523 .300 & 13.000 .021 .113 \\
\hline 8 & 14.222 .222 .488 & 14.252 .236 .000 & 13.222 .000 .010 \\
\hline 9 & 15.202 .224 .100 & 14.283 .732 .467 & 13.243 .099 .454 \\
\hline 10 & 14.000 .003 .200 & 14.522 .200 .000 & 11.258 .700 .000 \\
\hline 11 & 14.202 .300 .222 & 14.325 .623 .333 & 12.422 .200 .000 \\
\hline 12 & 15.000 .400 .000 & 14.500 .020 .000 & 12.200 .520 .000 \\
\hline Jumlah & 178.170 .217 .000 & 173.039 .586 .000 & 150.541 .972 .000 \\
\hline
\end{tabular}

Sumber: Bank BPR Mega Mas Lestari, 2019

Tabel 1.3 Perkembangan Profitabilitas PT. Bank BPR Mega Mas Lestari Tahun 2016-2018 Kabupaten Karimun

\begin{tabular}{|c|r|r|r|}
\hline \multirow{2}{*}{ Bulan } & \multicolumn{3}{|c|}{ Profitabilitas } \\
\cline { 2 - 4 } & Tahun 2016 & Tahun 2017 & \multicolumn{1}{c|}{ Tahun 2018 } \\
\hline 1 & 1.268 .628 .667 & 1.128 .349 .500 & 1.636 .045 .083 \\
\hline 2 & 1.266 .700 .000 & 1.125 .001 .000 & 1.636 .000 .000 \\
\hline 3 & 1.258 .600 .000 & 1.200 .010 .000 & 1.620 .830 .000 \\
\hline 4 & 1.163 .346 .670 & 1.126 .311 .500 & 1.633 .000 .000 \\
\hline 5 & 1.342 .200 .000 & 1.121 .005 .000 & 1.618 .220 .000 \\
\hline 6 & 1.286 .280 .000 & 1.200 .340 .000 & 1.646 .045 .000 \\
\hline 7 & 1.262 .000 .000 & 1.149 .741 .500 & 1.636 .045 .000 \\
\hline 8 & 1.256 .860 .000 & 1.199 .295 .000 & 1.702 .000 .000 \\
\hline 9 & 1.262 .000 .000 & 1.100 .030 .000 & 1.581 .770 .834 \\
\hline 10 & 1.260 .000 .000 & 1.100 .020 .000 & 1.666 .040 .000 \\
\hline 11 & 1.256 .700 .100 & 1.050 .081 .000 & 1.630 .500 .000 \\
\hline 12 & 1.340 .228 .563 & 1.040 .009 .500 & 1.626 .045 .083 \\
\hline Jumlah & 15.223 .544 .000 & 13.540 .194 .000 & 19.632 .541 .000 \\
\hline
\end{tabular}

Sumber: Bank BPR Mega Mas Lestari, 2019

\section{Identifikasi Masalah}

Permasalahan penelitian yang penulis ajukan ini dapat di identifikasi permasalahannya sebagai berikut;

1. Likuiditas Bank BPR Mega Mas Lestari mengalami peningkatan tahun 20162018, sedangkan jumlah pemberian kredit mengalami penurunan.

2. Profitabilitas mengalami penurunan tahun 2016-2018 sedangkan jumlah pemberian kredit BPR Mega Mas Lestari Kabupaten Karimun mengalami penurunan

\section{Hipotesa}

Menururt Sugiyono (2013;96), perumusan hipotesis emrupakan langkah ketiga dalam penelitian setelah mengemukakan kerangka berpikir dan landasan teori. 
Hipotesis merupakan jawaban sementara dari permasalahan yang akan diteliti. Hipotesis adalah jawaban sementara.

Ho1 $\neq 0$ : Tidak Terdapat pengaruh Likuditas secara signifikan terhadap Profitabilitas pada Bank Mega Mas Lestari Tahun 2016-2018 Kabupaten Karimun.

Ha1 $=0$ : Terdapat pengaruh Likuditas secara signifikan terhadap Profitabilitas pada Bank Mega Mas Lestari Tahun 2016-2018 Kabupaten Karimun.

Ho2 $\neq 0$ : Tidak terdapat pengaruh Pemberian kredit secara signifikan terhadap Profitabilitas pada Bank Mega Mas Lestari Tahun 2016-2018 Kabupaten Karimun.

Ha2 $=0$ : Terdapat pengaruh Pemberian kredit secara signifikan terhadap Profitabilitas pada Bank Mega Mas Lestari Tahun 2016-2018 Kabupaten Karimun.

Ho3 $\_0$ : Tidak terdapat pengaruh Likuiditas dan Pemberian kredit secara signifikan terhadap Profitabilitas pada Bank Mega Mas Lestari Tahun 2016-2018 Kabupaten Karimun.

Ha3 = 0 : Terdapat pengaruh Likuiditas dan Pemberian kredit secara signifikan terhadap Profitabilitas pada Bank Mega Mas Lestari Tahun 2016-2018 Kabupaten Karimun.

\section{A. Teori Keagenan}

Teori keagenan menurut Ramadona (2016) adalah teori yang berhubungan dengan perjanjian antar anggota di perusahaan. Teori ini menerangkan tentang pemantauan bermacam-macam jenis biaya dan memaksakan hubungan antara kelompok tersebut. Manajemen akan berusaha memaksimalkan kesejahteraan untuk dirinya sendiri dengan cara meminimalkan berbagai biaya keagenan, hal tersebut merupakan salah satu hipotesis dalam teori agency. Oleh sebab itu, perusahaan diharapkan akan memilih prinsip akuntansi untuk memaksimalkan kepentingannya dengan cara memilih prinsip akuntansi yang sesuai (Harahap, 2011). Agency theory merupakan suatu kontak principal serta agent. Principal menggunakan agent untuk bekerja dalam melakukan tugas dalam urusan principal, termasuk di dalamnya pelimpahan kekuasaan dari principal kepada agent.

\section{B. Bank}

Pengertian bank berdasarkan Undang-undang perbankan No. 10 tahun 1998 adalah "Badan usaha yang menghimpun dana dari masyarakat dalam bentuk kredit dan atau bentukbentuk lainnya dalam rangka meningkatkan taraf hifup rakyat banyak". Menurut Kasmir (2012:11) "pengertian bank adalah lembaga keuangan yang kegiatan utamanya adalah menghimpun dana dari masyarakat dan menyalurkannya kembali dana tersebut ke masyarakat serta memberikan jasa bank lainnya". Pengertian bank menurut Dendawijaya (2003:25) adalah "suatu badan yang bertujuan untuk memuaskan kebutuhan kredit, baik dengan alat-alat pembayarannya sendiri atau dengan uang yang diperolehnya dari orang lain, maupun dengan memperedar alat-alat penukar berupa uang”.

\section{a. Kegiatan Bank}

Menurut Kasmir (2012:4), kegiatan perbankan meliputi tiga kegiatan utama, yaitu:

1) Menghimpun dana (uang) dari masyarakat dalam bentuk simpanan, maksudnya dalam hal ini bank sebagai tempat menyimpan uang atau berinvestasi bagi 
masyarakat. Yang memiliki tujuan sebagai berikut: untuk keamanan uangnya, untuk melakukan investasi dengan harapan memperoleh bunga dari hasil simpanannya, dan untuk memudahkan transaksi pembayaran. Untuk memenuhi tujuan diatas, baik untuk mengamankan, uang maupun untuk melakukan transaksi, bank menyediakan sarana yang disebut dengan simpanan. Jenis simpanan bergantung pada masing-masing bank. Namun, secara umum jenis simpanan yang ada di bank adalah terdiri dari simpanan giro, simpanan tabungan, dan simpanan deposito.

2) Menyalurkan dana ke masyarakat, maksudnya adalah bank memberikan pinjaman (dana) kepada masyarakat yang mengajukan permohonan. Dengan kata lain, bank menyediakan dana bagi masyarakat yang membutuhkan. Pinjaman atau kredit yang diberikan di bagi delam berbagai jenis sesuai dengan keinginan nasabah. Tentu saja kredit yang diberikan bank terlebih dahulu harus dinilai apakah layak atau tidak. Penilaian ini dilakukan agar bank terhindar dari kerugian akibat tidak dapat dikembaikannya pinjaman yang disalurkan dengan berbagai sebab. Jenis kredit yang diberikan oleh hampir semua bank adalah seperti kredit investasi, kredit modal kerja, dan kredit perdagangan.

3) Memberikan jasa-jasa bank lainnya, seperti pengiriman uang (transfer), penagihan surat-surat berharga yang berasal dari dalam kota (kliring), penagihan surat-surat berharga yang berasal dari luar kota dan luar negeri (inkaso), letter of credit (L/C), safe deposit box, bank garansi, travelers cheque dan jasa lainnya

\section{Bank Perkreditan Rakyat (BPR)}

\section{a. Pengertian BPR}

Berdasarkan Undang-undang No. 10 Tahun 1998 tentang perbankan "Bank Perkreditan Rakyat adalah bank yang melaksanakan kegiatan usaha secara konvensional atau berdasarkan prinsip syariah yang dalam kegiatannya tidak memberikan jasa dalam lalu lintas pembayaran". Tujuan BPR Berdasarkan Undang-undang No. 10 Tahun 1998 tentang perbankan "Tujuan Bank Perkreditan Rakyat adalah untuk menunjang pelaksanaan pembangunan nasional dalam rangka meningkatkan pemerataan, penumbuhan ekonomi, dan stabilitas nasional ke arah peningkatan kesejahteraan rakyat banyak".

\section{b. Jenis BPR}

Berdasarkan Undang-undang No. 10 Tahun 1998 tentang perbankan BPR memiliki dua jenis BPR, yaitu:

1) BPR Konvensional

BPR Konvensional adalah Bank konvensional mendapatkan keuntungan dengan cara menetapkan bunga sebagai harga, baik untuk simpanan seperti giro, tabungan maupun deposito. Harga untuk pinjaman (kredit) juga ditentukan berdasarkan tingkat suku bunga sedangkan penetapan keuntungan untuk jasa bank lainnya ditetapkan biaya dalam nominal atau persentase tertentu.

2) BPR Syariah

BPR Syariah adalah salah satu lembaga keuangan perbankan syariah, yang pola operasionalnya mengikuti prinsip-prinsip syariah ataupun muamalah islam. BPR yang melakukan kegiatan usaha berdasarkan prinsip syariah selanjutnya diatur menurut Surat Keputusan Direktur 
Bank Indonesia No. 32/36/KEP/DIR/1999 tanggal 12 Mei 1999 tentang

Bank Perkreditan Rakyat Berdasarkan Prinsip Syariah

\section{Likuiditas}

Rasio likuiditas adalah rasio yang menunjukkan kemampuan perusahaan dalam memenuhi kewajiban atau membayar utang jangka pendeknya. Rasio inilah yang dapat digunakan untuk mengukur seberapa llikuidnya suatu perusahaan. Jika perusahaan mampu memenuhi kewajibannya berarti perusahaan tersebut likuid, sedangkan jika perusahaan tidak mampu memenuhi kewajibannya berarti perusahaan tersebut ilikuid. Cara mengukur perusahaan itu likuid atau tidak, Anda dapat membandingkan komponen yang ada pada neraca, yaitu total aktiva lancar dengan total pasiva lancar (utang jangka pendek). Pengukuran ini dapat dilakukan untuk beberapa periode sehingga terlihat perkembangan likuiditas perusahaan dari waktu ke waktu. Ada beberapa pengertian rasio likuiditas yaitu, menurut Subramanyam (2010) likuiditas merupakan kemampuan perusahaan untuk menghasilkan kas dalam jangka pendek untuk memenuhi kewajibannya dan bergantung pada arus kas perusahaan serta komponen asset dan kewajiban lancarnya. Menurut Sutrisno (2012) rasio likuiditas adalah rasio-rasio yang digunakan untuk mengukur kemampuan perushaan dalam membayar hutang-hutang jangka pendeknya. Menurut Kasmir (2014) menyebutkan bahwa rasio likuiditas (liquidity ratio) merupakan rasio yang menggambarkan kemampuan perusahaan dalam memenuhi kewajiban (utang) jangka pendek.

\section{E. Pemberian Kredit}

Kredit menurut Kasmir (2012:92) dalam buku Bank \& Lembaga Keuangan Lainnya, diartikan sebagai berikut: "Kredit adalah penyediaan uang atau tagihan yang dapat disamakan dengan itu, berdasarkan persetujuan atau kesepakatan pinjam meminjam antara bank dengan pihak lain yang mewajibkan pihak peminjam melunasi utangnya setelah jangka waktu tertentu dengan pemberian bunga." Jadi yang dimaksud dengan kredit dapat berupa uang atau tagihan yang nilainya diukur dengan uang, yang didalamnya akan tercakup hak dan kewajiban masing-masing pihak, termasuk waktu serta bunga, sanksi apabila peminjam ingkar janji terhadap perjanjian yang telah dibuat, semuanya dibuat atas kesepakatan bersama debitur dan kreditur.

\section{F. Profitabilitas}

Pengertian profitabilitas menurut para ahli yaitu Barus dan Leliani (2013), menyatakan bahwa Profitabilitas adalah kemampuan menghasilkan laba selama periode tertentu dengan menggunakan aktiva atau modal, baik modal secara keseluruhan maupun modal sendiri. Menurut Afriyanti (2011), Profitabilitas adalah kemampuan perusahaan memperoleh laba dalam hubungan dengan penjualan, total aktiva, maupun modal sendiri. Profitabilitas menggambarkan keberhasilan operasional perusahaan yang menunjukkan hasil akhir dari sejumlah kebijakan dan keputusan yang diambil oleh manajemen perusahaan. Menurut Weston dan Brigham dalam Sari (2013), profitabilitas juga menunjukkan pengaruh gabungan dari likuiditas, pengelolaan aktiva, dan pengelolaan hutang terhadap hasil-hasil operasi.

Berdasarkan pengertian rasio profitabilitas menurut para ahli di atas, dapat ditarik kesimpulan bahwa rasio profitabilitas adalah rasio untuk mengukur tingkat efektifitas pengelolaan manajemen perusahaan yang ditunjukkan oleh jumlah keuntungan yang dihasilkan dari penjualan dan investasi. Intinya adalah penggunaan rasio ini menunjukkan 
efisiensi perusahaan. Kemampulabaan (profitabilitas) merupakan hasil akhir bersih dari berbagai kebijakan dan keputusan manajemen. Rasio kemampulabaan akan memberikan jawaban akhir tentang efektivitas manajemen perusahaan, rasio ini memberi gambaran tentang tingkat efektivitas pengelolaan perusahaan (Sawir, 2009).

\section{METODE PENELITIAN}

\section{A. Jenis dan Sumber Data}

Sumber data penelitian merupakan faktor penting yang menjadi pertimbangan dalam penentuan metode pengumpulan data. Sumber data yang digunakan dalam penelitian ini adalah data sekunder. Adapun data sekunder yang diambil dalam laporan keuangan tahunan yang diperoleh di situs internet yaitu OJK mengenai Laporan Keuangan Bank BPR Mega MAs Lestari pada periode pengamatan 2016-2018

\section{B. Populasi dan Sampel}

Populasi dalam suatu penelitian perlu ditetapkan dengan tujuan agar penelitian yang dilakukan benar-benar mendapatkan data sesuai yang diharapkan. Menurut Sugiyono (2014:115) mendefinisikan populasi sebagai berikut: "Populasi adalah wilayah generalisasi yang terdiri atas: objek atau subyek yang mempunyai kualitas dan karakteristik tertentu yang ditetapkan oleh peneliti untuk dipelajari dan kemudian ditarik kesimpulannya". Populasi dalam penelitian ini adalah seluruh laporan keuangan Bank BPR Mega Mas Lestari periode 2016-2018, populasi sebanyak 36. Jumlah populasi dalam penelitian ini adalah sebanyak 36 bulan. sehingga presentase kelonggaran yang digunakan adalah 5\% dan hasil perhitungan dapat dibulatkan untuk mencapai kesesuaian. Maka untuk mengetahui sampel penelitian, dengan perhitungan sebagai berikut:

$$
\begin{aligned}
& \mathrm{n}=\frac{(36)}{1+36(0,05)^{2}} \\
& \mathrm{n}=\frac{(36)}{1+36(0,0025)}=33,027 \text { (diambil } 33 \text { bulan) }
\end{aligned}
$$

\section{Metode Analisis Data}

\section{1) Uji Normalitas}

Uji Normalitas adalah sebuah uji yang dilakukan dengan tujuan untuk menilai sebaran data pada sebuah kelompok data atau variabel, apakah sebaran data tersebut berdistribusi normal atau tidak. Uji normalitas data dilakukan dengan menggunakan uji Kolmogorov Smirnov menyatakan bahwa uji normalitas data dilihat dari hal tersebut, apabila:

a) Nilai Asymp.Sig (2-tailed) lebih besar dari 0,05, maka data terdistribusi normal

b) Nilai Asymp.Sig (2-tailed) lebih kecil dari 0,05, maka data terdistribusi normal (Ghozali, 2013). 


\section{2) Uji Heterokedasdisitas}

Uji heteroskedastisitas bertujuan untuk menguji apakah dalam model regresi terjadi ketidaksamaan variance dari residual satu pengamataan ke pengamatan yang lain tetap, atau disebut homoskedastisitas. Model regresi yang baik adalah yang homoskedastisitas, tidak heteroskedastisitas. Heteroskedastisitas ditandai dengan adanya pola tertentu pada grafik scatterplot. Jika titik-titik yang ada membentuk suatu pola tertentu yang teratur (bergelombang), maka terjadi heteroskedastisitas. Jika tidak ada pola yang jelas, titik-titik menyebar di atas dan di bawah angka nol pada sumbu Y, maka tidak terjadi heteroskedastisitas.

\section{3) Uji Multikolonieritas}

Uji Multikolinieritas, uji ini dimaksudkan untuk mendeteksi gejala korelasi antara variabel independen yang satu dengan variabel independen yang lain. Pada model regresi yang baik seharusnya tidak terdapat korelasi di antara variabel independen. Uji Multikolinieritas dapat dilakukan dengan 2 cara yaitu dengan melihat:

a) VIF (Variance Inflation Factors) dan nilai tolerance.

b) Jika VIF $>10$ dan nilai tolerance $<0,10$ maka terjadi gejala Multikolinieritas (Ghozali, 2009).

\section{4) Uji Auto Korelasi}

Uji Autokorelasi, bertujuan untuk menguji apakah ada korelasi antar anggota sampel atau data pengamatan yang diurutkan berdasarkan waktu, sehingga munculnya suatu data dipengaruhi oleh data sebelumnya. Dalam penelitian ini bila terjadi Autokorelasi, berarti CSR selain dipengaruhi oleh Variabel Independen juga dipengaruhi oleh CSR pada periode sebelumnya.

\section{Uji Analisis}

\section{Uji Regresi Linier Berganda}

Analisis data dalam penelitian ini menggunakan analisis Regresi Linier Berganda. Analisis ini digunakan untuk melihat pengaruh variabel dependen dan variabel independen yang jumlahnya lebih dari dua variabel. Adapun persamaan model Regresi Linier Berganda tersebut adalah:

$$
\mathrm{Y}=\mathrm{a}+\mathrm{b}_{1} \mathrm{x}_{1}+\mathrm{b}_{2} \mathrm{x}_{2}
$$

Keterangan :

Y : Nilai prediksi variabel dependen (kinerja organisasi)

a : Konstanta

$\mathrm{b}_{1}, \mathrm{~b}_{2}$ : Koefisien variabel bebas

$\mathrm{X}$ : Variabel independen 
Angka peningkatan atau penurunan variabel dependen yang didasarkan pada variabel independen. Bila b (+) maka naik, bila b (-) maka terjadi penurunan.

\section{E. Uji Hipotesis}

\section{Uji T (Parsial)}

Hipotesis adalah jawaban sementara terhadap rumusan masalah penelitian. Kebenaran dari hipotesis itu harus dibuktikan melalui data yang terkumpul. Langkah-langkah dalam pengujian hipotesis ini dimulai dengan menetapkan hipotesis nol (Ho) dan hipotesis alternative (Ha),

\section{Uji F (Simultan)}

Selanjutnya, untuk hipotesis secara bersama-sama (simultan) digunakan Uji F. Uji F digunakan untuk mengetahui apakah variabel-variabel independen secara bersama-sama berpengaruh terhadap dependen.

\section{F. Uji Determinan}

Setelah koefisien korelasi diketahui, maka langkah selanjutnya adalah menghitung koefisien detrminasi yaitu untuk mengetahui besarnya pengaruh variabel independen terhadap variabel dependen. Menurut Gujarati (2012:172) utuk melihat besar pengaruh dari setiap variabel independen terhadap variabel dependen secara parsial. Koefisien determinasi merupakan kuadrat dari koefisien korelasi sebagai ukuran untuk mengetahui kemampuan dari masing-masing variabel yang digunakan dalam penelitian.

\section{HASIL DAN PEMBAHASAN}

\section{A. Uji T}

\begin{tabular}{|c|c|c|c|c|c|c|}
\hline \multicolumn{7}{|c|}{ Coefficients $^{a}$} \\
\hline & & \multicolumn{2}{|c|}{$\begin{array}{l}\text { Unstandardized } \\
\text { Coefficients }\end{array}$} & \multirow{2}{*}{$\begin{array}{c}\begin{array}{c}\text { Standardized } \\
\text { Coefficients }\end{array} \\
\text { Beta }\end{array}$} & \multirow[b]{2}{*}{$\mathrm{t}$} & \multirow[b]{2}{*}{ Sig. } \\
\hline \multicolumn{2}{|c|}{ Model } & $B$ & Std. Error & & & \\
\hline \multirow[t]{3}{*}{1} & (Constant) & 8.289E8 & $4.496 \mathrm{E} 8$ & & 1.844 & .075 \\
\hline & Likuiditas & 6.989 & .925 & .859 & 7.553 & .000 \\
\hline & Kredit & -.024 & .025 & -.109 & -.955 & .347 \\
\hline
\end{tabular}

Tabel 3.1 Uji T

Nilai t hitung variabel Likuiditas (X1) adalah sebesar 7.553. Karena nilai thitung (7.553) > t Tabel $(2,042)$ dan nilai signifikan (Sig) variabel Likuiditas (X1) adalah sebesar 0,000, nilai Sig 0,000 < 0,05. maka dapat disimpulkan bahwa Ha1 diterima dan H01 ditolak, artinya terdapat pengaruh yang signifikan antara Likuiditas (X1) terhadap Profitabilitas(Y)

NIlai t hitung, diketahui variabel Pemberian Kredit (X2) adalah sebesar 0,955. Karena nilai thitung $(0,955)<\mathrm{t}$ Tabel $(2,042)$, dan nilai signifikan (Sig) variabel Pemberian Kredit (X2) adalah sebesar 0,347, dimana nilai Sig 0,347 >0,05. Maka dapat 
disimpulkan bahwa $\mathrm{Ha} 2$ ditolak dan $\mathrm{H} 02$ diterima. Artinya tidak ada pengaruh yang signifikan antara Pemberian Kredit (X2) terhadap Profitabilitas (Y).

\section{B. Uji F}

\begin{tabular}{|l|r|r|l|l|l|}
\hline Model & Sum of Squares & df & $\begin{array}{l}\text { Mean } \\
\text { Square }\end{array}$ & F & Sig. \\
\hline 1 Regression & $1.304 \mathrm{E} 18$ & 2 & $6.519 \mathrm{E} 17$ & 162.883 & $.000^{\mathrm{a}}$ \\
Residual & $1.201 \mathrm{E} 17$ & 30 & $4.002 \mathrm{E} 15$ & & \\
Total & $1.424 \mathrm{E} 18$ & 32 & & & \\
\hline
\end{tabular}
a. Predictors: (Constant), Kredit, Likuiditas
b. Dependent Variable: Profitabilitas

Tabel 3.2 Uji F

Nilai F hitung sebesar 162.883. Karena nilai Fhitung (162.883) > F Tabel $(3,305)$ maka Ha3 Diterima dan dan Ho3 Ditolak. Nilai F hitung berdasarkan nilai Sig. sebesar $0,000<0,05$, maka Hipotesis Ha3 diterima dan H03 ditolak. Artinya Terdapat pengaruh Likuiditas (X1) dan Pemberian Kredit (X2) secara simultan terhadap Profitabilitas (Y).

\section{Uji Determinasi}

\begin{tabular}{|l|c|c|c|c|}
\hline \multicolumn{5}{|c|}{ Model Summary } \\
\hline Model & $\mathrm{R}$ & $\mathrm{R}$ Square & $\begin{array}{c}\text { Adjusted R } \\
\text { Square }\end{array}$ & $\begin{array}{c}\text { Std. Error of the } \\
\text { Estimate }\end{array}$ \\
\hline 1 & $.957^{\mathrm{a}}$ & .916 & .910 & $6.32637 \mathrm{E} 7$ \\
\hline $\begin{array}{l}\text { a. Predictors: (Constant), Kredit, Likuiditas } \\
\text { b. Dependent Variable: Profitabilitas }\end{array}$ \\
\hline
\end{tabular}

Tabel 3.3 Uji determinasi

Nilai Adjusted $R$ Square sebesar 0,916. Artinya bahwa kontribusi nilai X1 dan X2 dalam menjelaskan variable $\mathrm{Y}$ ialah sebesar $91.6 \%$ dan dan sisanya $8,4 \%$ dijelaskan oleh variable lain diluar variable yang diuji.

\section{A. Kesimpulan}

\section{KESIMPULAN}

Dari penelitian yang dilakukan, maka kesimpulannya adalah:

1. Uji t (Parsial) membuktikan Hipotesis Pertama (Ha1) diterima, artinya terdapat pengaruh signifikan antara Likuiditas (X1) terhadap Profitabilitas (Y), dimana nilai thitung $(7,553)>\mathrm{t}$ Tabel $(2,042)$, dan berdasarkan nilai signifikan, Nilai sig $0,000<0,05$.

2. Uji t (Parsial) membuktikan Hipotesis Kedua (Ha2) ditolak, artinya tidak terdapat pengaruh signifikan antara Pemberian Kredit (X2) terhadap Profitabilitas (Y), dimana nilai thitung $(0,955)<\mathrm{t}$ Tabel $(2,042)$, dan berdasarkan nilai signifikan, Nilai sig $0,347>0,05$. 
3. Uji f (simultan) membuktikan Hipotesis ketiga (Ha3) diterima artinya terdapat pengaruh signifikan antara Likuiditas (X1) dan Pemberian Kredit (X2) terhadap Profitabilitas (Y), dimana nilai F hitung sebesar 162.883. Karena nilai Fhitung $(162.883)>$ F Tabel $(3,305)$ dan berdasarkan nilai sig $0,00<0,05$ maka Ha3 Diterima dan Ho3 Ditolak.

4. Uji Determinan membuktikan nilai $R$ Square 0,916 dengan variabel independen $\mathrm{X} 1$ dan $\mathrm{X} 2$. Artinya bahwa kontribusi nilai X1 dan X2 dalam menjelaskan variabel Y ialah sebesar 91,6\% dan dan sisanya8,6\% dijelaskan oleh variabel lain diluar variabel yang diuji.

\section{B.Saran}

Berdasarkan kesimpulan diatas, maksa saran yang dijadikan sebagai masukan sesuai dengan penelitian ini adalah:

1. Pemberian kredit Bank BPR Mega Mas Lestari berdasarkan analisa tahun Tahun 2016, 2017 dan 2018 nilainya menurun sehingga lebih buruk dari tahun sebelumnya, tetapi perusahaan masih mampu meningkatkan proftitabilitas. Agar peningkatan ini tetap meningkat diharapkan kemampuan bank untuk menggunakan modal sendiri sehingga mengalami peningkatan laba yang dihasilkan perusahaan.

2. Pemberian kredit disebabkan karena macetnya pembayaran, maka diharapkan bank mampu menganalisa nasabah yang mampu diberi pinjaman agar terhindar dari likuiditas

\section{DAFTAR PUSTAKA}

Agnes Sawir, 2009. Analisa Kinerja Keuangan dan Perencanaan keauangan. Perusahaan. PT. Gramedia Pustaka Utama. Jakarta

Dendawijaya Lukman. 2003. Manajemen Perbankan, Edisi kedua. Ghalia Indonesia. Jakarta

Harahap, Sofyan Safri .2011. Teori Akuntansi, Edisi Revisi. PT Raja Gralindo Persada Jakarta

Kasmir. 2011. Analisis Laporan Keuangan. PT Raja Grafindo Persada. Jakarta 2012. Bank dan Lembaga Kuangan Lainnya. PT. Raja Grafindo. Persada. Jakarta

Sugiyono. (2014). Metode Penelitian Pendidikan Pendekatan Kuantitatif, Kualitatif, dan R\&D. Alfabeta. Bandung 